\title{
NEW RECORDS OF LICHENS FROM TASMANIA, PRINCIPALLY FROM THE 2018 TMAG EXPEDITION OF DISCOVERY TO MUSSELROE BAY
}

\author{
by Gintaras Kantvilas, Brian J. Coppins, Patrick M. McCarthy and John A. Elix
}

(with two plates)

\begin{abstract}
Kantvilas, G., Coppins, B.J., McCarthy, P.M. \& Elix, J.A. 2020 (9:xii). New records of lichens from Tasmania, principally from the 2018 TMAG Expedition of Discovery to Musselroe Bay. Papers and Proceedings of the Royal Society of Tasmania 154: 1-8. https://doi.org/10.26749/rstpp.154.1 Tasmanian Herbarium, Tasmanian Museum and Art Gallery, Box 5058, UTAS LPO, Sandy Bay, Tasmania 7005, Australia (GK). Royal Botanic Garden Edinburgh, 20A Inverleith Row, Edinburgh, EH3 5LR, United Kingdom (BJC). 64 Broadsmith St, Scullin, A.C.T. 2614, Australia (PMMcC). Research School of Chemistry, Building 137, Australian National University, Canberra, A.C.T. 2601, Australia (JAE). Author for correspondence: Email: Gintaras.Kantvilas @tmag.tas.gov.au

Nineteen lichen species are recorded for the first time from Tasmania: Amandinea conranensis Elix \& P.M.McCarthy, Bacidia laurocerasi (Delise ex Duby) Zahlbr., Buellia extenuatella Elix \& Kantvilas, Catinaria atropurpurea (Schaer.) Vězda \& Poelt, Collema crispum (Huds.) Weber ex F.H.Wigg., Diploschistes enganeus (A.Massal.) J.Steiner, D. gyrophoricus Lumbsch \& Elix, Endocarpon crassisporum P.M.McCarthy \& Filson, Gyalecta pellucida (Coppins \& Malcolm) Baloch \& Lücking, Lecanora pseudogangaleoides Lumbsch subsp. pseudogangaleoides, L. strobilina (Spreng.) Kieff., Opegrapha niveoatra (Borrer) J.R.Laundon, O. spodopolia Nyl., O. varia Pers., Physcia austrostellaris Elix, Ramonia absconsa (Tuck.) Vězda, Trapelia concentrica Elix \& P.M.McCarthy and Xanthoparmelia xerica (Elix) Elix. The new combination Austroparmelina corrugativa (Kurok. \& Filson) Elix \& Kantvilas is proposed and Austroparmelina euplectina (Kurok. ex Elix). A.Crespo et al. is reduced to synonymy. The salient morphological and anatomical features, ecology and distribution are discussed for each species. Key Words: lichenised fungi, taxonomy, floristics, Austroparmelina.
\end{abstract}

\section{INTRODUCTION}

Since the first checklists of Tasmanian lichens, for example those of Wetmore (1963), which listed 421 taxa, Kantvilas (1989: 633 taxa) and Kantvilas (1994: 762 taxa), the number of lichens recorded for Tasmania has risen steadily and now stands at 1309 (McCarthy 2020). The increases have been derived from taxonomic revision of existing herbarium collections, fortuitous and ad hoc collecting, as well as targeted studies of particular locations (e.g. Jarman \& Kantvilas 1994, Kantvilas et al. 2012), vegetation types (Jarman \& Kantvilas 1995, Kantvilas \& Jarman 2012) and taxonomic groups (e.g. Kantvilas 2012, Kantvilas \& Coppins 2019). More recently, a formal survey program, the Tasmanian Museum and Art Gallery Expeditions of Discovery, has been initiated with the express aim of, inter alia, discovering new or hitherto overlooked species in Tasmania. The first of these expeditions, undertaken in 2017 in the Little Swanport area on Tasmania's east coast (Baker et al. 2019), proved exceptionally productive for lichens. Of the 170 species recorded, two were described as new to science (Elix et al. 2019a, McCarthy \& Kantvilas 2018) and a further 19 were new records for Tasmania (Elix et al. 2019b, Baker et al. 2019); additional putative new taxa await further study. The second expedition was undertaken in late 2018 to the Cape Portland-Musselroe Bay area in the far northeast of Tasmania. Lichens again proved to be a rich source of novelties and, whereas an inventory of species will be presented elsewhere, new records for Tasmania are documented here. As with previous accounts of this nature, some of the discoveries arose entirely from fieldwork conducted during the expedition. In other cases, the expedition identification work prompted a broader investigation of herbarium collections, and the novelties in question were found to be represented by additional specimens from other Tasmanian localities. It is particularly noteworthy that two of the new records are of species previously known only from their respective type collections: Ramonia absconsa (from South Carolina, U.S.A.) and Xanthoparmelia xerica (from South Australia).

\section{MATERIAL AND METHODS}

The study is based chiefly on material collected by the first author during the TMAG Expedition of Discovery at Musselroe Bay, northeastern Tasmania, during November 2018, and a second, follow-up field trip in September 2019. Specimens are housed in the Tasmanian Herbarium (HO), with selected duplicates sent to other herbaria as indicated in the text. Additional reference herbarium material, chiefly from $\mathrm{HO}$, was also consulted. Anatomical and morphological observations were undertaken using light microscopy, with thin hand-cut sections mounted in water, $10 \% \mathrm{KOH}(\mathrm{K})$, lactophenol cotton blue, Lugol's iodine after pre-treatment with dilute $\mathrm{KOH}, 50 \% \mathrm{HNO}_{3}(\mathrm{~N})$ and ammoniacal erythrosin. Routine chemical analyses using thin-layer chromatography follow standard methods (Elix 2014). Nomenclature of lichen asci mainly follows Hafellner (1984). Ascospore measurements are presented either in the format: 5 th percentile-average- 95 th percentile, with outlying values given in brackets and $n$ being the number of measurements, or as a simple range. 


\section{THE SPECIES}

\section{Amandinea conranensis Elix \& P.M.McCarthy}

Characterised by a crustose thallus not containing any substances detectable by thin-layer chromatography, black apothecia 0.1-0.3 mm wide, 1-septate, Buellia-type ascospores, 9-14 $\times 5-8 \mu \mathrm{m}$, constricted at the septum when older, and filiform conidia, $12-21 \times 0.7-1 \mu \mathrm{m}$ (see Elix $e t$ al. 2017). It is most similar to the common $A$. punctata (Hoffm.) Coppins \& Scheid., which has larger ascospores $(10-20 \times 5-9 \mu \mathrm{m})$ that do not become constricted. The Tasmanian specimen was collected from a fencepost in a paddock. The species also occurs in Victoria and New South Wales where it is an epiphyte in coastal situations.

TASMANIA: Cape Portland, Musselroe Wind Farm, Tregaron Lagoons, vicinity of Turbine D8, 40 47'38"S $148^{\circ} 05^{\prime} 24^{\prime \prime E}, 30 \mathrm{~m}$ alt., 10 Sep. 2019, G. Kantvilas $256 / 19(\mathrm{HO})$

\section{Austroparmelina corrugativa (Kurok. \& Filson) Elix \& Kantvilas comb. nov. \\ MycoBank No. MB834192}

Parmelia corrugativa Kurok. \& Filson, Bull. Natl Sci. Mus. ser. B, 1: 38 (1975); Pseudoparmelia corrugativa (Kurok. \& Filson) Hale, Smithsonian Contr. Bot. 31: 25 (1976); Canoparmelia corrugativa (Kurok. \& Filson) Elix \& Hale, Mycotaxon 27: 278 (1986). Type: South Australia: near Balhannah, 3 June 1966, R.W. Rogers 553 (holo- MEL!).

Parmelina euplectina Kurok. ex Elix, Mycotaxon 47: 116 (1993); Austroparmelina euplectina (Kurok. ex Elix). A.Crespo, Divakar \& Elix, in Crespo et al., Syst. \& Biodiv. 8: 216 (2010). Type: New South Wales: Raymond Terrace to Bulahdelah Road, N of Karuah, 9 May 1965, R.B. Filson 7176 (holo- MEL!)

With its grey foliose thallus of rather rounded, imbricate lobes containing lecanoric acid (medulla $\mathrm{C}+\mathrm{red}$ ), black underside with an extensive, pale brown marginal zone, and lack of isidia or soredia, this species closely resembles the common and widespread $A$. pseudorelicina (Jatta) A.Crespo et al. It differs by containing the orange pigment euplectin $(\mathrm{K}+$ violet $)$, visible as a thin, orange layer in the lower part of the medulla. In Tasmania, this species occurs as an epiphyte in dry sclerophyll woodland and scrub in the northeast of the State where it is usually sympatric with A. pseudorelicina. It has a similar ecological distribution in southeastern Australia.

TASMANIA: Glen Esk Road near Middle Run Hill, $41^{\circ} 48^{\prime} \mathrm{S} 147^{\circ} 27^{\prime} \mathrm{E}, 220 \mathrm{~m}$ alt., 24 Aug. 2001, G. Kantvilas 754/01 (HO); Sawpit Hill Road, c. $1 \mathrm{~km} \mathrm{SE}$ of Diabobble Hill, $41^{\circ} 31^{\prime} \mathrm{S} 147^{\circ} 23^{\prime} \mathrm{E}, 420 \mathrm{~m}$ alt., 5 Sep. 2001, G. Kantvilas 815/01 (HO); Tomahawk River, $40^{\circ} 52^{\prime}$ S $147^{\circ} 45^{\prime}$ E, sea-level, 1 June 2003, G. Kantvilas 108/03
(HO); Cape Portland, Musselroe Wind Farm, Tregaron Lagoons, "Copperhead Road", 4046'49"S 14758'00"E, 2 m alt., 9 Nov. 2018, G. Kantvilas 326/18, 328/18 (HO).

\section{Bacidia laurocerasi (Delise ex Duby) Zahlbr.}

This name has been variously applied in herbaria to specimens from Australia and elsewhere, often incorrectly. Based on the comprehensive account by Ekman (1996) and comparison with reliably identified reference specimens, it is characterised as follows:

Thallus crustose, pale brownish grey to greenish grey. Apothecia biatorine, $0.3-0.8 \mathrm{~mm}$ diam.; disc reddish brown to dark brown or blackish, sometimes a little piebald, matt, epruinose, plane at first, later becoming convex; proper exciple concolorous with the disc or a little paler at the upper edge, usually pale reddish brown at the sides, persistent or becoming reduced and inapparent in the oldest, most convex apothecia, in section 60-90 $\mu \mathrm{m}$ thick, colourless within, at the edges reddish brown to purplish brown, $\mathrm{K} \pm$ purplish brown, $\mathrm{N}+$ orange-brown, lacking crystalline inclusions. Hypothecium 50-100 $\mu \mathrm{m}$ thick, colourless to pale yellowish, intensifying yellowish in K. Hymenium 65-85 $\mu \mathrm{m}$ thick, not inspersed, colourless, with a brown to purplish brown epihymenial layer, $\mathrm{K}+$ purple-brown intensifying, $\mathrm{N}+$ orange-brown. Ascospores acicular, tapered towards the distal end, side-by-side or loosely coiled in the ascus, (40-)42-56.6-70(-72) × 3-3.5-4(-4.5) $\mu \mathrm{m}(n=$ 40), with $12-17$ septa distinct in water. Chemistry: no substances detected (plate 1A).

Critically, this species lacks any greenish, $\mathrm{N}+$ crimson-red pigments, a feature that separates it from the otherwise similar B. wellingtonii (Stirt.) D.J.Galloway. In Tasmania, $B$. laurocerasi appears to be associated with lowland, often swampy Melaleuca ericifolia-dominated vegetation. In Australia, it has been recorded with certainty from Kangaroo Island (Kantvilas 2019), but other records remain unconfirmed.

TASMANIA: Moores Hill near Beaconsfield, $41^{\circ} 14^{\prime} \mathrm{S}$ 146 ${ }^{\circ} 52^{\prime}$ E, 80 m alt., 27 Apr. 1981, G. Kantvilas 256/81A (HO); Tatlows Beach Coastal Reserve, 40 $47^{\prime} \mathrm{S} 145^{\circ} 17^{\prime} \mathrm{E}$, $1 \mathrm{~m}$ alt., 15 May 2019, G. Kantvilas 154/19 (HO); Cape Portland, Musselroe Wind Farm, between Petal Point Road and Tregaron Lagoons, $40^{\circ} 47^{\prime} \mathrm{S} 147^{\circ} 58^{\prime} \mathrm{E}, 10 \mathrm{~m}$ alt., 9 Nov. 2018, G. Kantvilas 343/18 (HO).

\section{Buellia extenuatella Elix \& Kantvilas}

This species is superficially similar to Amandinaea conranensis and $A$. punctata in having a highly reduced thallus and black apothecia, but is distinguished by the combination of a scurfy, membranaceous or sorediate upper surface, Buellia-type ascospores, 11-19 $\times 5-8 \mu \mathrm{m}$, and bacilliform conidia, (3-)4-6 $\times 0.5-1 \mu \mathrm{m}$. The Tasmanian specimen was epiphytic in Allocasuarina-dominated woodland, a habitat consistent with its occurrence on the southern Australian mainland (Elix \& Kantvilas 2013). 

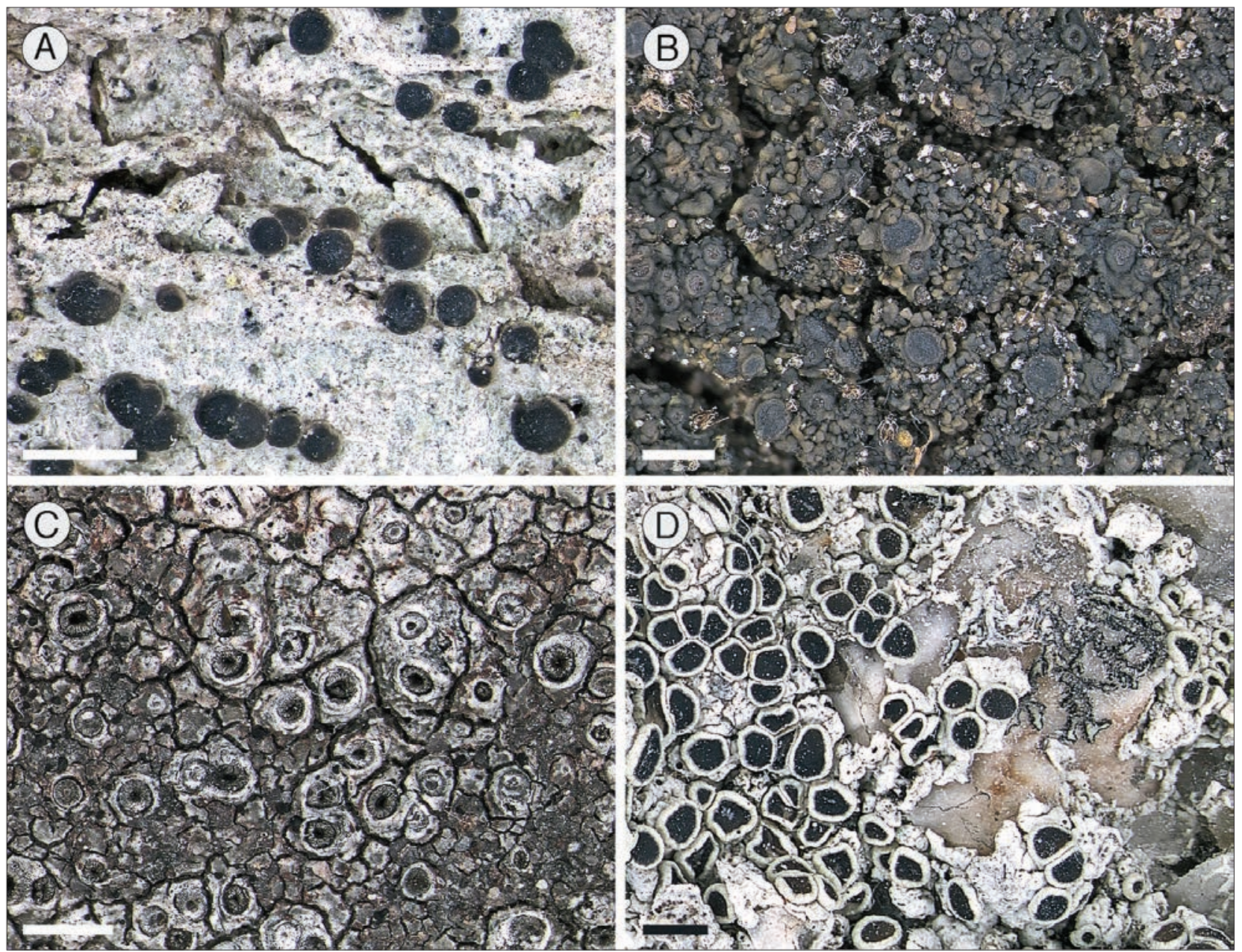

PLATE 1 - (A) Bacidia laurocerasi, with apothecia with a dark disc and a somewhat paler margin. (B) Collema crispum, showing the dark squamulose thallus with small, dark coloured apothecia. (C) Diploschistes gyrophoricus, with perithecioid ascomata.

(D) Lecanora pseudogangaleoides subsp. pseudogangaleoides. Scales $=1 \mathrm{~mm}$.

TASMANIA: Cape Portland, Musselroe Wind Farm: "Cadaver Ridge", 4048'28"S 14804'05"E, 65 m alt., 11 Sep. 2019, G. Kantvilas 225/19 (HO).

\section{Catinaria atropurpurea (Schaer.) Vězda \& Poelt}

Characterised by a thin, undelimited crustose thallus, the typically reddish brown to blackish brown, biatorine apothecia, $0.2-0.8 \mathrm{~mm}$ wide, the 8-spored, Catillaria-type asci where the well-developed tholus is uniformly amyloid and lacks internal differentiation, the slender, paraphyses with reddish brown, swollen apices, and the hyaline, ellipsoid, 1 -septate ascospores, $10-17 \times 5-7.5 \mu \mathrm{m}$, with a gelatinous perispore $c .1 \mu \mathrm{m}$ thick. Ascus structure distinguishes this species readily from several superficially similar genera, especially Megalaria, which also has 1-septate ascospores. Catinaria atropurpurea is widespread in temperate regions throughout the world. In Tasmania, it occurs on the bark of various trees and shrubs, mainly in coastal vegetation, but has rarely also been recorded inland in wet forest.
TASMANIA: Flinders Island, Yellow Beaches, $40^{\circ} 13^{\prime} \mathrm{S}$ 148 $15^{\prime}$ E, 2 m alt., 8 Aug. 1978, J.S. Whinray 1231 p.p. (HO); Cape Deslacs, 42 $59^{\prime} \mathrm{S} 147^{\circ} 33^{\prime} \mathrm{E}, 1$ Jun. 1980, G. Kantvilas 231/80 (BM, HO); Swan Basin, 42 $12^{\prime} \mathrm{S}$ $145^{\circ} 16^{\prime} \mathrm{E}$, sea-level, 21 Jan. 2000, G. Kantvilas 33/00

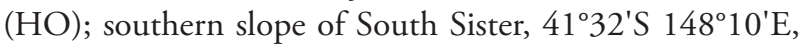
640 m alt., 10 Nov. 2004, G. Kantvilas 377/04A (HO); Florentine Bridge, $42^{\circ} 30^{\prime} \mathrm{S} 146^{\circ} 27^{\prime} \mathrm{E}, 360 \mathrm{~m}$ alt., 2 Nov. 2005, G. Kantvilas 315/05 (HO); Little Musselroe River estuary, 4046'S $148^{\circ} 03^{\prime} \mathrm{E}, 5 \mathrm{~m}$ alt., 6 Nov. 2018, G. Kantvilas 181/18 (HO); St Helens Point, 10 m alt., 2020, G. Kantvilas 99/20 (HO).

\section{Collema crispum (Huds.) Weber ex F.H.Wigg.}

Characterised by a thallus of minute, squamiform lobes and lobules mostly up to $c .0 .2 \mathrm{~mm}$ wide, and conspicuous apothecia to $1 \mathrm{~mm}$ wide, with a red-brown to blackbrown, plane disc, a proper exciple of elongate (rather than paraplectenchymatous) hyphae, and 3-septate ascospores, $22-34 \times 10-16 \mu \mathrm{m}$, occasionally with an additional longitudinal or oblique septum (plate 1B). In Tasmania, this species has been recorded on man-made substrata 
(for example, the mortar of a ruined building) as well as on calcarenite in coastal heathland, and it has a similar distribution and ecology in other parts of the world (Gilbert et al. 2009). In his monumental work, Degelius (1974) did not formally record C. crispum from Tasmania, although he noted the existence of sterile specimens which might be this species. One such annotated specimen (G.C. Bratt 70/568, $\mathrm{HO}$ ) was located but is considered here to be Collema subflaccidum Degel.

TASMANIA: Flinders Island, Trousers Point, $40^{\circ} 13^{\prime} \mathrm{S}$ $148^{\circ} 02^{\prime}$ E, $10 \mathrm{~m}$ alt., 23 Mar. 2014, G. Kantvilas 368/14 (BG, HO); Cape Portland, Musselroe Wind Farm, The

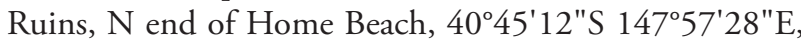
10 m alt., 8 Nov. 2018, G. Kantvilas 299/18, 302/18 (HBG, HO).

\section{Diploschistes euganeus (A.Massal.) J.Steiner}

Diploschisteseuganeus is one in a complex of morphologically similar species which grows on non-calcareous rocks and has perithecioid ascomata (Mangold et al. 2009). It is characterised best by lacking lichen substances, a feature that distinguishes it from D. gyrophoricus and D. sticticus (Körb) Müll.Arg. (with gyrophoric acid) and from D. aeneus (Müll.Arg.) Lumbsch and D. actinostomus (Pers.) Zahlbr. (both with lecanoric acid). This widespread species has a scattered Tasmanian distribution on exposed rocks in low rainfall areas and displays a similar ecology in other parts of temperate Australia.

TASMANIA: Glen Morey Saltpan, near Tunbridge, $42^{\circ} 09^{\prime} \mathrm{S} 147^{\circ} 29^{\prime} \mathrm{E}, 180 \mathrm{~m}$ alt., 8 Nov. 1984, A. Moscal 8802 (HO); Cape Portland, $40^{\circ} 45^{\prime} \mathrm{S} 147^{\circ} 57^{\prime} \mathrm{E}, 5 \mathrm{~m}$ alt., 8 Nov. 2018, G. Kantvilas 282/18 (HO).

\section{Diploschistes gyrophoricus Lumbsch \& Elix}

Like the preceding species, D. gyrophoricus is one of a group of morphologically similar species with perithecioid ascomata (plate 1C). It is characterised by the presence of gyrophoric acid and is distinguished from the chemically identical $D$. sticticus by subtle differences in the size and shape of its muriform ascospores. In $D$. gyrophoricus, these are $(18-) 20-23.3-27(-30) \times(11-) 13.5-15.5-18(-20)$ $\mu \mathrm{m}$, broadly ovate-ellipsoid with broadly rounded apices, and with a length/width ratio of 1.3-1.5-1.8 (Tasmanian specimens, $n=55$ ). In contrast, the ascospores of $D$. sticticus are ellipsoid and relatively longer and narrower: (22-)2434.9-40 $(-42) \times(11-) 12-17.1-20(-21) \mu \mathrm{m}$, with a length / width ratio of 1.7-2.0-2.4 (Tasmanian specimens, $n=$ 28). Diploschistes gyrophoricus is widespread in Tasmania on exposed rocks in rough pasture and dry sclerophyll woodland. It is also known from southeastern mainland Australia, New Zealand and South America.

TASMANIA: Hunting Grounds, Dysart, 42³4'S $147^{\circ} 10^{\prime} \mathrm{E}, 400 \mathrm{~m}$ alt., 7 Aug. 1981, G. Kantvilas 473/81 \& P.W. James (HO); Spiky Bridge, $42^{\circ} 11^{\prime} \mathrm{S} 148^{\circ} 04^{\prime} \mathrm{E}, 0$ m alt., 2 Feb. 1984, G. Kantvilas 166/84 \& P.W. James

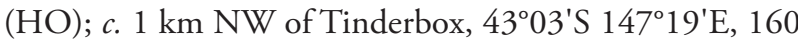
m alt., 23 Jul. 2015, G. Kantvilas 253/15 (HO); 'Wind

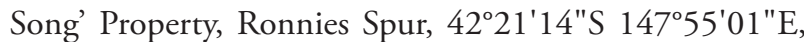
$30 \mathrm{~m}$ alt., 25 Oct. 2017, G. Kantvilas 238/17 (HO); Cape Portland, Musselroe Wind Farm, woodland W of Xanthorrhoea Ridge, 4047'53"S 148 $01^{\prime} 08^{\prime}$ E, $70 \mathrm{~m}$ alt., 6 Nov. 2018, G. Kantvilas 365/18 (HO).

\section{Endocarpon crassisporum P.M.McCarthy \& Filson}

With its grey-brown to reddish brown squamae, c. 2-10 mm wide, this species is superficially similar to E. simplicatum (Nyl.) Nyl., the most common species of Endocarpon in Tasmania. It is characterised by its consistently 1-spored asci and large, brown, muriform ascospores, 80-130 $\times$ (30-) 40-60 $\mu \mathrm{m}$ (see McCarthy 2001). It was found on consolidated, dolerite-derived soil in a very degraded coastal tussock grassland with extensive patches of bare soil and pebbles, a habitat consistent with its ecology on the Australian mainland.

TASMANIA: Cape Portland, $\mathrm{N}$ of Semaphore Hill, $40^{\circ} 45^{\prime} \mathrm{S} 147^{\circ} 57^{\prime} \mathrm{E}, 10 \mathrm{~m}$ alt., 8 Nov. 2018, G. Kantvilas 252/18 (HO).

\section{Gyalecta pellucida (Coppins \& Malcolm) Baloch \& Lücking}

This taxon was initially described in the genus Belonia by Coppins and Malcolm (1998) on account of its crustose thallus with a Trentepohlia photobiont, its pale pink, perithecioid apothecia, $0.2-0.3 \mathrm{~mm}$ wide, that have a proper exciple of rounded cells, thin-walled asci with a non-amyloid tholus but a thin, faintly amyloid wall, and acicular ascospores, $60-80 \times 2.2-3(-4) \mu \mathrm{m}$, with $c$. 35-45 transverse septa. The genus Gyalecta in the traditional sense differs chiefly by having apothecioid ascomata with a plane to strongly concave or urceolate disc, and ellipsoid to fusiform, transeptate or muriform ascospores. The close relationship between these two genera was established by DNA-sequence data (Baloch et al. 2010). Gyalecta pellucida is an extremely inconspicuous species, very rare in Tasmania where it has been recorded from blackwood (Acacia melanoxylon)- or paper-bark (Melaleuca ericifolia)-dominated coastal swamps; it is also known from New Zealand.

TASMANIA: Stanley Peninsula, c. $30 \mathrm{~m} \mathrm{E}$ of Wells Road, $40^{\circ} 45^{\prime} \mathrm{S} 145^{\circ} 17^{\prime} \mathrm{E}$, c. $50 \mathrm{~m}$ alt., 28 Feb. 1998, A. Gray s.n. (HO); Cape Portland, Musselroe Wind Farm, northern end of Musselroe Bay, 4048'36"S 14806'41"E, sea-level, 11 Sep. 2019, G. Kantvilas 239/19 (HO).

\section{Lecanora pseudogangaleoides Lumbsch subsp. pseudogangaleoides}

Characterised by a prominent, continuous, yellowish grey to greenish grey thallus containing atranorin, usnic acid and 
psoromic acid, and apothecia $0.5-1.3 \mathrm{~mm}$ wide, with a redbrown to black-brown disc and with large crystals, insoluble in $\mathrm{KOH}$, in the margin; see Lumbsch and Elix (2004) for a complete description (plate 1D). The presence of psoromic acid, which distinguishes it from the very similar L. wilsonii Müll.Arg., can usually be detected by the $\mathrm{P}+$ yellow reaction of the thallus. In Tasmania, this lichen is known only from outcrops of granite or quartzite in coastal heathland and dry sclerophyll woodland. It is also recorded from southeastern mainland Australia.

TASMANIA: The Gnomon, $41^{\circ} 11^{\prime} \mathrm{S} 146^{\circ} 02^{\prime} \mathrm{E}, 475 \mathrm{~m}$ alt., 25 May 1991, G. Kantvilas 236/91 (HO); unnamed hill c. $1 \mathrm{~km}$ NE of Coles Bay township, $42^{\circ} 07^{\prime} \mathrm{S} 148^{\circ} 17^{\prime} \mathrm{E}$, 100 m alt., 23 Apr. 2007, G. Kantvilas 170/07 (HO); Cape Portland, Musselroe Wind Farm, "The Prairie", in the vicinity of Turbine D14, 40 48'35"S 148 06'23"E, $20 \mathrm{~m}$ alt., 11 Sep. 2019, G. Kantvilas 248/19, 251/19 (CANB, HO).
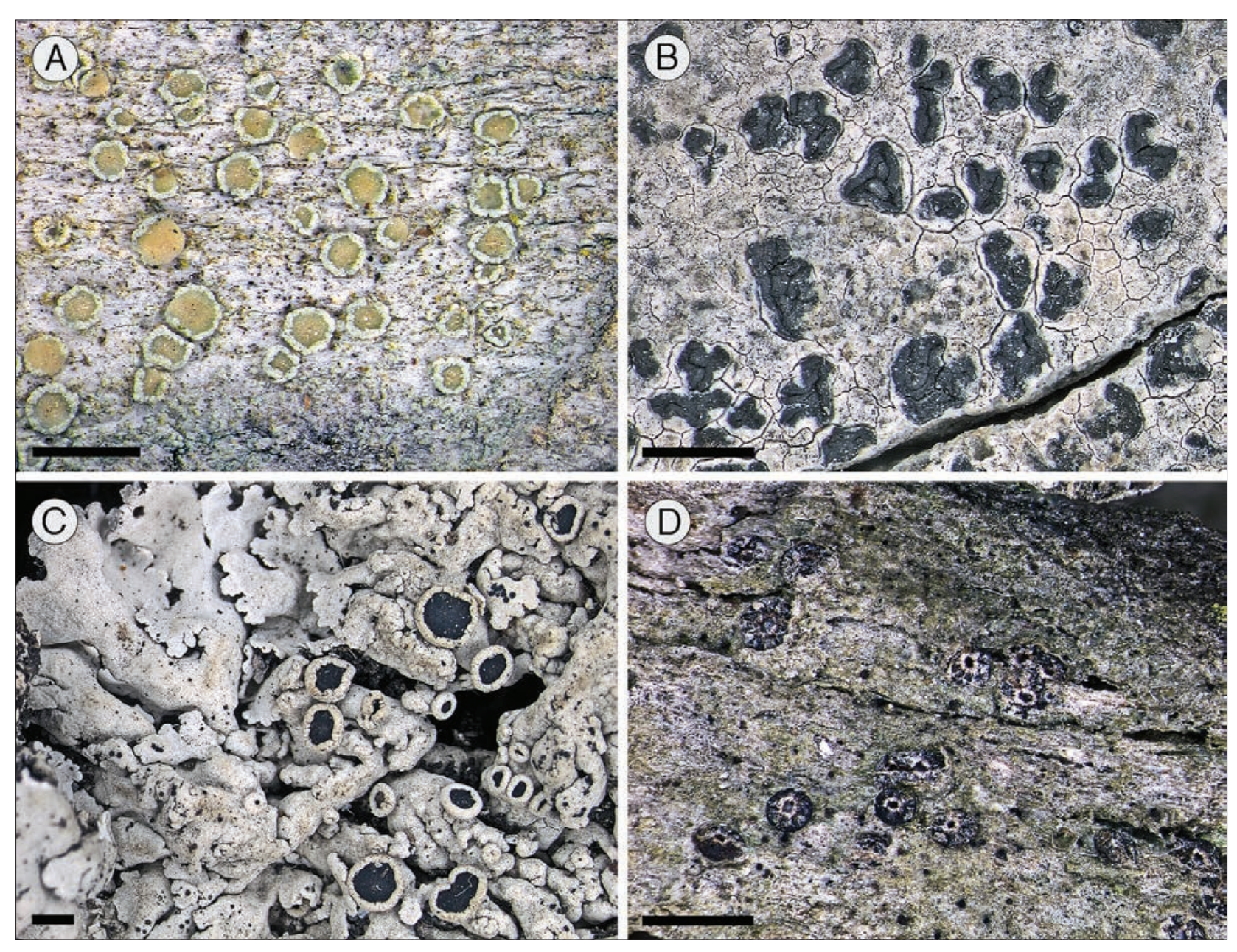

PLATE 2 - (A) Lecanora strobilina; note the apothecia with a persistent, crenulate, thalline margin. (B) Opegrapha spodopolia, with irregular, lirelliform apothecia with a central slit. (C) Physcia austrostellaris. (D) Ramonia absconsa, with tiny, semi-immersed apothecia with a central apical pore. Scales $=1 \mathrm{~mm}$.

\section{Lecanora strobilina (Spreng.) Kieff.}

Lecanora strobilina is a member of the L. symmicta group, and the latter name has been broadly applied in Australia to specimens that contain atranorin and zeorin and have yellowish to brownish biatorine apothecia. As noted in several studies of Australian specimens (e.g. Lumbsch \& Elix 2004, Kantvilas \& LaGreca 2008, Pérez-Ortega \& Kantvilas 2018), the group is complex and individual taxa can be difficult to distinguish. Even so, several species of the L. symmicta group are recognised in Tasmania, namely L. helmutii Pérez-Ortega \& Kantvilas, L. subtecta (Stirt.) Kantvilas \& LaGreca and L. coppinsiarum Kantvilas, as well as L. symmicta (Ach.) Ach. itself. Similar problems of species delimitation occur in the Northern Hemisphere (LaGreca \& Lumbsch 2013), where L. strobilina is distinguished essentially by having apothecia with a persistent, crenulate thalline margin (plate 2A).

The Lecanora symmicta group was well-represented in the Musselroe Bay survey and included: L. subtecta, distinguished by having bright yellow, often pruinose, biatorine apothecia; L. symmicta, with pale yellow, 
epruinose, biatorine apothecia; and a third entity with persistently lecanorine apothecia with a prominent crenulate margin. The name L. strobilina is applied to this last taxon, pending a more detailed review of the entire group. This lichen was observed frequently on bleached, split-eucalypt fenceposts and droppers in paddocks, as well as in patches of native vegetation where it grew on dead, standing wood.

TASMANIA: Cape Portland, Musselroe Wind Farm: vicinity of Turbine D8, 40 47'38"S $148^{\circ} 05^{\prime} 24^{\prime \prime E}, 30$ m alt., 10 Sep. 2019, G. Kantvilas 252/19 (HO, MA); northern end of Musselroe Bay, 4048'36"S 14806'41"E, sea-level, 11 Sep. 2019, G. Kantvilas 232/19 (HO, MA); "Cadaver Ridge", 4048'28"S 14804'05"E, 65 m alt., 11 Sep. 2019, G. Kantvilas 224/19 (HO).

\section{Opegrapha niveoatra (Borrer) J.R.Laundon}

Characterised by simple, straight or curved lirellae, 0.4-1 $\mathrm{mm}$ long, with a black, $\mathrm{K}+$ olive exciple (in section), and (3-)7-septate, acicular ascospores, $22-40 \times 3.5-4 \mu \mathrm{m}$, with all cells \pm equal in size (Pentecost $\&$ James 2009, Kantvilas 2019). In Tasmania, this \pm cosmopolitan species has been collected mainly on Melaleuca ericifolia and appears to have a widely scattered distribution in the State.

TASMANIA: Passage Island, Bass Strait, $40^{\circ} 31^{\prime} \mathrm{S}$ $148^{\circ} 19^{\prime} \mathrm{E}, 11 \mathrm{~m}$ alt., 11 Oct. 1979, J.S. Whinray 1331 (MEL); Moores Hill, near Beaconsfield, $41^{\circ} 14^{\prime} \mathrm{S} 146^{\circ} 52^{\prime} \mathrm{E}$, 80 m alt., 27 Apr. 1981, G. Kantvilas 253/81 (HO);

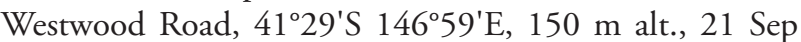
2005, A.M. Buchanan 16307b (HO); Cape Portland, Musselroe Wind Farm, Tregaron Lagoons, "Copperhead Road”, 4046'46"S 14757'58"E, 2 m alt., 9 Nov. 2018 , G. Kantvilas 324/18 (HO).

\section{Opegrapha spodopolia Nyl.}

This species is characterised by the following salient characters: thallus pale grey, cream-grey or fawn brown, occasionally somewhat scurfy; ascomata lirelliform, black, mostly $0.3-0.6 \mathrm{~mm}$ long and up to $0.4(-0.6)$ wide, mostly elongate but sometimes approximately as long as wide; exciple usually highly convoluted, contorted and sulcate, closed or gaping at the apex, invariably open at the base, in section $\mathrm{K}+$ olive-greenish; hymenium inspersed with oil droplets, with a brown, $\mathrm{K}+$ pale olive epihymenial layer; ascospores (4-)5-6(-7)-septate, 20-26(-30) × 4-6 $\mu \mathrm{m}$, with a gelatinous perispore that swells in $\mathrm{KOH}$ and becomes roughened with age; conidia rod-shaped, 4-6 $\times 0.5-1 \mu \mathrm{m}$ (plate $2 \mathrm{~B}$ ). Originally described from New Zealand, this species was recently recorded from Kangaroo Island, South Australia (Kantvilas 2019). It is widespread along the coastlines of Tasmania, occurring on a wide variety of rock types including dolerite, quartzite, granite, serpentinite and mudstone. It grows in the rocky littoral zone in shaded sheltered overhangs. The genus Opegrapha is still poorly known in Tasmania. Many herbarium collections of saxicolous and corticolous species are yet to be identified, not least from coastal rocks. Features that best distinguish $O$. spodopolia are the basally open exciple and the dimensions and septation of the ascospores.

TASMANIA: Sleepy Bay, $42^{\circ} 08^{\prime} \mathrm{S} 148^{\circ} 19^{\prime} \mathrm{E}$, sea-level, 2 Feb. 1984, G. Kantvilas 143/84 \& P. James (BM, HO); Hibbs Pyramid, 42³6'S 145¹6'E, 4 Feb. 1984, A. Moscal 6128c (HO); Doctors Rocks, $41^{\circ} 01^{\prime} \mathrm{S} 145^{\circ} 47^{\prime} \mathrm{E}$, sea-level, 19 Feb. 1984, G. Kantvilas 391/84 \& P. James (BM, H,

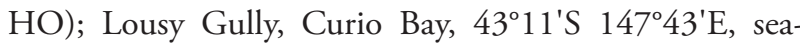
level, 4 Feb. 2001, G. Kantvilas 154/01 (HO); Maingon Blowhole, $43^{\circ} 12^{\prime} \mathrm{S} 147^{\circ} 51^{\prime} \mathrm{E}, 40 \mathrm{~m}$ alt., 14 Oct. 2006, G. Kantvilas 359/06 (HO); Lion Rock, 4336'S 14649'E, sea-level, 27 Dec. 2007, G. Kantvilas 435/07 (HO); Mars Bluff, Bruny Island, $43^{\circ} 15^{\prime} \mathrm{S} 147^{\circ} 24^{\prime} \mathrm{E}, 5 \mathrm{~m}$ alt., 15 Mar. 2008, G. Kantvilas 40/08; Lion Rock, 4336'S 14649'E, $1 \mathrm{~m}$ alt., 21 Apr. 2013, G. Kantvilas 34/13 (HO); mouth of Interview River, $41^{\circ} 35^{\prime} \mathrm{S} 144^{\circ} 53^{\prime} \mathrm{E}, 3 \mathrm{~m}$ alt., $31 \mathrm{Jan}$ 2015, G. Kantvilas 142/15 (HO); Goat Island, $41^{\circ} 08^{\prime} \mathrm{S}$ $146^{\circ} 08^{\prime} \mathrm{E}, 5 \mathrm{~m}$ alt., 24 Oct. 2016, G. Kantvilas 388/16 (HO); Cape Portland, Musselroe Wind Farm, shoreline near the Stone House, $40^{\circ} 45^{\prime} \mathrm{S} 148^{\circ} 01^{\prime} \mathrm{E}, 2 \mathrm{~m}$ alt., 9 Nov. 2018, G. Kantvilas 151/18 (HO); Cape Portland, $40^{\circ} 44^{\prime} 40^{\prime S} 147^{\circ} 56^{\prime} 29^{\prime \prime E}, 2 \mathrm{~m}$ alt., 8 Nov. 2018, G. Kantvilas 261/18 (HO); northern end of Godfreys Beach, Stanley, $40^{\circ} 45^{\prime} \mathrm{S} 145^{\circ} 18^{\prime} \mathrm{E}, 1 \mathrm{~m}$ alt., 13 May 2019, G. Kantvilas 170/19 (HO).

\section{Opegrapha varia Pers.}

Characterised by relatively short lirellae with a $\mathrm{K} \pm$ brown exciple, and the fusiform, 4-6-septate ascospores, 18-38 $\times$ $6-8 \mu \mathrm{m}$, in which the central cell is noticeably enlarged. In Tasmania, this species has a scattered, coastal distribution and grows on wood or bark. It has been widely recorded throughout the world, including from mainland Australia. A detailed description is offered by Pentecost and James (2009).

TASMANIA: Flinders Island, Cave Beach, $40^{\circ} 01^{\prime} \mathrm{S}$ $147^{\circ} 53^{\prime} \mathrm{E}, 5 \mathrm{~m}$ alt., 23 Jan. 2006, G. Kantvilas 84/06 (HO); Bonnet Island, Macquarie Harbour, $42^{\circ} 13^{\prime} \mathrm{S}$ $145^{\circ} 13$ 'E, $1 \mathrm{~m}$ alt., 14 May 2013, G. Kantvilas 144/13 (HO); Flinders Island, The Dock, 39 $48^{\prime} \mathrm{S} 147^{\circ} 52^{\prime} \mathrm{E}, 10$ m alt., 21 Mar. 2014, G. Kantvilas 298/14 (HO); Cape Portland, Musselroe Bay Conservation Area, Abalone Rocks, 4047'26"S 14806'08"E, 3 m alt., 7 Nov. 2018 , G. Kantvilas 388/18 (HO)

\section{Physcia austrostellaris Elix}

Characterised by an essentially orbicular thallus, with radiating, \pm rounded, esorediate lobes to $c .2 \mathrm{~mm}$ wide at the margins, a pale brown to ivory under-surface, apothecia to $2.5 \mathrm{~mm}$ wide, with a brown-black disc that is often thickly greyish pruinose, and by the presence of the triterpene, 20a-acetoxyhopane-6a,22-diol, in addition to atranorin (plate 2C). Although found occasionally in dry sclerophyll vegetation, where it occurs on the bark of understorey trees such as Allocasuarina, or on wood or rocks, this species is 
most commonly seen on exotic trees in parks and along roadsides. The Musselroe Bay specimen was collected from dolerite boulders in an Allocasuarina verticillata-dominated woodland. In earlier literature pertaining to Australian lichens, this species was referred to as P. stellaris (L.) Nyl., a name now applied strictly to a superficially similar Northern Hemisphere species that differs by having narrower lobes, often with secondary lobules in the centre of the thallus, numerous, simple or branched, whitish to dark brown or grey rhizines that often protrude beyond the lobe margins and lacks any triterpenes additional to atranorin (Elix et al. 2009).

TASMANIA: Poatina, $41^{\circ} 48^{\prime S} 146^{\circ} 58^{\prime} \mathrm{E}, 900 \mathrm{~m}$ alt., Jan. 1964, G.C. Bratt 1315 (HO); Lake Tooms Road, 4203'S $147^{\circ} 30^{\prime}$ E, 19 Dec. 1974, G.C. Bratt 74/1245 \& M. Gilbert (HO); Reeves Creek, Picnic Rocks, 4059'S 148¹9'E, 20 m alt., 13 Sep. 1983, A. Moscal 2668 (HO); Red Rocks, $41^{\circ} 00^{\prime} \mathrm{S} 148^{\circ} 19^{\prime} \mathrm{E}, 20 \mathrm{~m}$ alt., 19 Oct. 1983, A. Moscal 3646 (HO); Campbell Town, 41 ${ }^{\circ} 56^{\prime} \mathrm{S} 147^{\circ} 29^{\prime} \mathrm{E}, 14 \mathrm{Feb} .1984$, G. Kantvilas 454/84 \& P. James (BM, HO); Don Heads, $41^{\circ} 10^{\prime} \mathrm{S} 146^{\circ} 20^{\prime} \mathrm{E}, 3 \mathrm{~m}$ alt., 27 May 1990, G. Kantvilas 282/90 (HO); 2 km W of New Norfolk, Glenora Road, $42^{\circ} 47^{\prime} \mathrm{S} 147^{\circ} 02^{\prime} \mathrm{E}, 90 \mathrm{~m}$ alt., 19 Feb. 1997, G. Kantvilas 72/97 (HO); St Helens, $41^{\circ} 19^{\prime} \mathrm{S} 148^{\circ} 14^{\prime} \mathrm{E}, 10 \mathrm{~m}$ alt., 20 Feb. 2001, G. Kantvilas 270/01 (HO); Evandale, edge

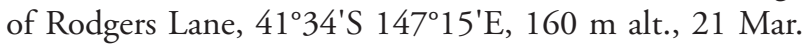
2001, J. Jarman s.n. (HO); Glen Esk Road near Middle Run Hill, 41 ${ }^{\circ} 48^{\prime} \mathrm{S} 147^{\circ} 27^{\prime} \mathrm{E}, 220 \mathrm{~m}$ alt., 24 Aug. 2001, G. Kantvilas 755/01 (HO); Windmill Hill, Launceston,

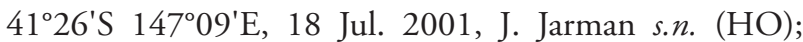
Auburn Road, $42^{\circ} 00^{\prime S} 147^{\circ} 19^{\prime} \mathrm{E}, 230 \mathrm{~m}$ alt., 12 Dec. 2001, G. Kantvilas 1297/01 (HO); Mole Creek, 41 $34^{\circ}$ 'S $146^{\circ} 24^{\prime}$ E, 240 m alt., 2 Mar 2002, G. Kantvilas 141/02 (HO); Cape Portland, Musselroe Wind Farm, woodland W of Xanthorrhoea Ridge, 4047'53"S 148 01'08"E, 70 m alt., 6 Nov. 2018, G. Kantvilas 357/18 (HO).

\section{Ramonia absconsa (Tuck.) Vězda}

This species is characterised by the following salient features: thallus crustose, effuse, very thin and patchy, pale greygreen, with a Trentepohlia photobiont; apothecia $0.3-0.5$ $\mathrm{mm}$ wide, at first immersed or semi-immersed and visible as a 'bump' in the thallus, pierced by a minute central pore with a grey rim, emergent when mature, becoming globose to hemispherical, with a dark brown, strongly incurved, radially split proper exciple, and a central pore to $c .0 .15 \mathrm{~mm}$ wide, revealing a pale grey, urceolate disc; exciple in section cupulate, hyaline to brown, composed of rhomboidal or subglobose, parenchymatous cells 3-7 $\mu \mathrm{m}$ wide and lined along the inner edge with periphyses 5-10 $\times 2-3 \mu \mathrm{m}$; asci 32-spored, of the Gyalecta-type, with a thin, $\mathrm{KI}+$ blue wall and non-amyloid, poorly developed tholus; ascospores (12) 13-19(-20) ×5-6.5(-7) $\mu \mathrm{m}, 3(-5)$-septate, ellipsoid, blunt or acute at the apices, with a gelatinous perispore (plate 2D).

This is a remarkable discovery for Tasmania, based on a single collection from the papery bark of an old
Melaleuca ericifolia in a lowland, coastal swamp. Prior to this collection, it was known only from the type specimen, collected in the nineteenth century from the bark of maple in South Carolina, U.S.A. (Vězda 1966, 1967).

TASMANIA: Cape Portland, Musselroe Wind Farm, Tregaron Lagoons, 4046'55"S 14758'09"E, $2 \mathrm{~m}$ alt., 2019, G. Kantvilas 230/19 (E, HO).

\section{Trapelia concentrica Elix \& P.M.McCarthy}

Recently described from New South Wales and the A.C.T. by Elix and McCarthy (2019), this species is characterised by a thallus of minute, highly dispersed, scabrid areoles to $0.3 \mathrm{~mm}$ wide, scattered apothecia to $c .0 .5 \mathrm{~mm}$ wide, and ascospores 11-17 × 6-10 $\mu \mathrm{m}$. Elix and McCarthy (2019) compare it to T. crystallifera Kantvilas and Elix, which in Tasmania occurs exclusively on soil. However, the single Tasmanian specimen of T. concentrica is from rock, and is therefore more likely to be confused with the common, widespread and highly variable T. coarctata (Sm.) M.Choisy. It grew on dolerite pebbles in a highly degraded tussock grassland.

TASMANIA: Cape Portland, N of Semaphore Hill, $40^{\circ} 45^{\prime} \mathrm{S} 147^{\circ} 57^{\prime} \mathrm{E}, 10 \mathrm{~m}$ alt., 8 Nov. 2018, G. Kantvilas 253/18B (HO).

The genus Trapelia in Tasmania is complex and requires considerable further study. An additional, as yet unidentified species was also collected at the study site (Kantvilas 226/19; HO). It grew on consolidated soil and had scattered, sorediate squamules containing gyrophoric acid, and ascospores $24-31 \times 12-17 \mu \mathrm{m}$.

\section{Xanthoparmelia xerica (Elix) Elix}

Characterised by an almost subcrustose, grey or blackened thallus of minute, tightly adnate lobes, mostly only to $0.1 \mathrm{~mm}$ wide, which become rather spidery at the thallus margins, with a pale brown underside, sparse, globose isidia and containing atranorin and stictic acid. Previously known only from the type locality on the Eyre Peninsula, South Australia, this rare lichen was collected in Tasmania on a granite boulder in coastal scrubby heathland. It could potentially be confused with the very common and widespread $X$. mougeotina and X. xanthomelaena with which it grows, both of which contain stictic acid but differ by also containing usnic acid instead of atranorin, and have a black under-side; the latter differs further in lacking isidia.

TASMANIA: Cape Portland, Musselroe Wind Farm, "The Prairie", in the vicinity of Turbine D14, 4048'35"S $148^{\circ} 06^{\prime} 23^{\prime \prime E, ~} 20$ m alt., 5 Nov. 2018, G. Kantvilas 210/18 (HO).

\section{ACKNOWLEDGEMENTS}

The 2018 TMAG Expedition of Discovery was generously 
supported by Woolnorth Wind Farm Holding Pty Ltd and the Friends of the Tasmanian Museum and Art Gallery. Jean Jarman prepared the images that accompany this paper.

\section{REFERENCES}

Baker, M., Grove, S., de Salas, M., Byrne, C., Cave, L., Bonham, K., Moore, K. \& Kantvilas G. 2019: Tasmanian Museum and Art Gallery's Expedition of Discovery 1 - The flora and fauna of Wind Song, Little Swanport, Tasmania. Papers and Proceedings of the Royal Society of Tasmania 153: 5-30.

Baloch, E., Lücking, R., Lumbsch. H.T. \& Wedin, M. 2010: Major clades and phylogenetic relationships between lichenized and non-lichenized lineages in Ostropales (Ascomycota: Lecanoromycetes). Taxon 59: 1483-1494.

Coppins, B.J. \& Malcolm, W.M. 1998: A new Belonia from New Zealand and a second record of $B$. mediterranea. Lichenologist 30: 563-566.

Degelius, G. 1974: The lichen genus Collema with special reference to the extra-European species. Symbolae Botanicae Upsalienses 20(2): 1-215.

Ekman, S. 1996: The corticolous and lignicolous species of Bacidia and Bacidina in North America. Opera Botanica 127: 1-148.

Elix, J.A. 2014: A Catalogue of Standardized Chromatographic Data and Biosynthetic Relationships for Lichen Substances. Third Edition. Canberra: published by the author

Elix, J.A. \& Kantvilas, G. 2013: New taxa and new records of Buellia sensu lato (Physciaceae, Ascomycota) in Australia. Australasian Lichenology 73: 24-44.

Elix, J.A. \& McCarthy, P.M. 2019: Trapelia concentrica (lichenized Ascomycota, Trapeliaceae), a new species from south-eastern Australia, with a key to the genus in Australia. Australasian Lichenology 85: 46-50.

Elix, J.A., Corush, J. \& Lumbsch, H.T. 2009: Triterpene chemosyndromes and subtle morphological characters characterise lineages in the Physcia aipolia group in Australia (Ascomycota). Systematics and Biodiversity 7: 479-487.

Elix, J.A., Kantvilas, G. \& McCarthy, P.M. 2017: Thirteen new species and a key to buellioid lichens (Caliciaceae, Ascomycota) in Australia. Australasian Lichenology 81: 26-67.

Elix, J.A., Kantvilas, G. \& McCarthy, P.M. 2019a: Two new species of Rinodina (Physciaceae, Ascomycota) from southern Australia. Australasian Lichenology 84: 10-15.

Elix, J.A., Kantvilas, G., McCarthy, P.M. \& Archer, A.W. 2019b: Additional lichen records from Australia. Australasian Lichenology 84: 55-71.

Gilbert, O.L., James, P.W. \& Purvis, O.W. 2009: Collema F.H.Wigg. (1780). In Smith, C.W., Aptroot, A., Coppins, B.J., Fletcher, A., Gilbert, O.L., James, P.W. \& Wolseley, P.A. (eds): The Lichens of Great Britain and Ireland, London, British Lichen Society: 345-357.

Hafellner, J. 1984: Studien in Richtung einer natürlicheren Gliederung der Sammelfamilien Lecanoraceae und Lecideaceae. Beiheft zur Nova Hedwigia 79: 241-371.

Jarman, S.J. \& Kantvilas, G. 1994: Lichens and bryophytes of the Tasmanian World Heritage Area. II. Three forest sites at Pelion Plains. Tasforests 6: 103-120.

Jarman, S.J. \& Kantvilas, G. 1995: A floristic study of rainforest bryophytes and lichens in Tasmania's myrtle-beech alliance. Tasmanian NRCP Report No. 14. Forestry Tasmania and Department of Environment, Sport \& Territories, Canberra.

Kantvilas, G. 1989: A checklist of Tasmanian lichens. Papers and Proceedings of the Royal Society of Tasmania 123: 67-85.

Kantvilas, G. 1994: A revised checklist of the Tasmanian lichen flora. Muelleria 8: 155-175.

Kantvilas, G. 2012: The genus Menegazzia (Lecanorales: Parmeliaceae) in Tasmania revisited. Lichenologist 44: 189-246.

Kantvilas, G. 2019: An annotated catalogue of the lichens of Kangaroo Island, South Australia. Swainsona 32: $1-97$.

Kantvilas, G. \& Coppins, B.J. 2019: Studies on Micarea in Australasia II. A synopsis of the genus in Tasmania, with the description of ten new species. Lichenologist 51: 431-481.

Kantvilas, G. \& Jarman, S.J. 2012: Lichens and bryophytes in Tasmanian wet eucalypt forest: floristics, conservation and ecology. Phytotaxa 59: 1-31.

Kantvilas, G. \& LaGreca, S. 2008: Lecanora subtecta, an Australian species in the Lecanora symmicta group. Muelleria 26: 72-76.

Kantvilas, G., Jarman, S.J. \& McCaffrey, N. 2012: A contribution to the flora of the Meredith Range, north-western Tasmania. Kanunnah 5: 127-140.

LaGreca, S. \& Lumbsch. H.T. 2013: Taxonomic investigation of Lecanora strobilina and L. symmicta (Lecanoraceae, Lecanorales) in northeastern North America. The Bryologist 116: $287-295$.

Lumbsch, H.T. \& Elix, J.A. 2004: Lecanora. Flora of Australia 56A: $12-62$.

Mangold, A., Elix, J.A. \& Lumbsch, H.T. 2009: Thelotremataceae. Flora of Australia 57: 195-420.

McCarthy, P.M. 2001: Endocarpon. Flora of Australia 58A: 161-167.

McCarthy, P.M. 2020: Checklist of the Lichens of Australia and it Island Territories. Australian Biological Resources Study, Canberra. Version 1, March 2020. http://www.anbg.gov. $\mathrm{au} / \mathrm{abrs} /$ lichenlist/introduction.html.

McCarthy, P.M. \& Kantvilas, G. 2018: Anisomeridium disjunctum (Monoblastiaceae), a new lichen species from Tasmania, with a key to the genus in Australia. Australasian Lichenology 83: $54-60$.

Pentecost, A. \& James, P.W. 2009: Opegrapha Ach. (1809). In Smith, C.W., Aptroot, A., Coppins, B.J., Fletcher, A., Gilbert, O.L., James, P.W. \& Wolseley, P.A. (eds): The Lichens of Great Britain and Ireland, London, British Lichen Society: 631-647.

Pérez-Ortega, S. \& Kantvilas, G. 2018: Lecanora helmutii, a new species from the Lecanora symmicta group from Tasmania. Herzogia 31 (1) Teil 2: 639-649.

Vězda, A. 1966: Flechtensystematische Studien III. Die Gattungen Ramonia Stiz. und Gloeolecta Lett. Folia Geobotanica et Phytotaxonomica Praha 1: 154-175.

Vězda, A. 1967: Flechtensystematische Studien V. Die Gattung Ramonia Stiz. Zusätze. Folia Geobotanica et Phytotaxonomica Praha 2: 311-317.

Wetmore, C.M. 1963: Catalogue of the lichens of Tasmania. Revue Cryptogamie Bryologique et Lichénologique 32: 223-264.

(Accepted 15 July 2020) 